UDC 159.9 : 316.6

\title{
O. Y. BLYNOVA ${ }^{1 *}$, L. S. HOLOVKOVA ${ }^{2 *}$, O. V. SHEVIAKOV ${ }^{3 *}$
}

\author{
1*Kherson State University (Kherson, Ukraine), e-mail elena.blynova@ gmail.com, ORCID 0000-0003-3011-6082 \\ 2* Dnipropetrovsk National University of Railway Transport named after Academician V. Lazaryan (Dnipro, Ukraine), \\ e-mail g.liudmila22@gmail.com, ORCID 0000-0001-5473-6644 \\ 3*'Dniprovskii University of Humanities (Dnipro, Ukraine), e-mail shevyakovy0@ gmail.com, ORCID 0000-0001-8348-1935
}

\section{PHILOSOPHICAL AND SOCIOCULTURAL DIMENSIONS OF PERSONALITY PSYCHOLOGICAL SECURITY}

Purpose. The dynamics and pace of social and economic transformations that are characteristic of modern society, lead to an increase in tension and the destruction of habitual stereotypes - ideals, values, norms, patterns of behaviour that unite people. These moments encourage us to rethink the understanding of "security" essence, in particular, psychological, which emphasizes the urgency of its study in the philosophical and sociocultural coordinates. Theoretical basis of the research is based on the philosophical methodology of K. Jaspers, E. Fromm and the A. Maslow's psychological approach to understanding of a person. Originality. Psychological security is considered at different levels: first and foremost, society is a characteristic of social security, that is an analysis of how today's social technologies, social changes affect the quality of life of the country's population; secondly, the social environment - the family, the immediate environment, reference groups, training teams; thirdly, a person is an experience of his own security-insecurity, when it is possible to talk about the manifestations of psychological violence, when certain behavioral acts contribute to the violation of the security of the other or to selfdestruction. It is found out that the knowledge of psychological security is closely connected with the sociohistorical conditions of being, with the level of development of material and spiritual culture, with the interests and values prevailing in society, which determines its ontological, epistemological and axiological features. The presented issue is considered in the correlation of psychological security with types of scientific rationality classical, nonclassical and post-nonclassical approaches, within the framework of which various perspectives, aspects, forms and types of psychological security are studied. Conclusions. The concept of security requires a systematic description of its manifestations, types, levels, concepts: security as the absence of dangers (based on the principle of dichotomy, that is, a certain whole consisting of two opposite parts, in this case, the whole is human existence); security as a certain activity to ensure or to prevent any threats or dangers (activity approach); security as a conscious necessity, the value of the individual. The study systematizes various ideas about psychological security in accordance with the logic of scientific knowledge: in the mainstream of classical, non-classical and post-nonclassical approaches.

Keywords: security; social security; subjective security; psychological security; educational security; philosophical and sociocultural dimensions of securities

\section{Introduction}

Security problems concern not only each person, but also set a number of philosophical, legal, political, sociological, psychological and other special issues. An analysis of modern literature on various aspects of the study of security problems suggests that currently security is a complex, interdisciplinary field of knowledge, and the role of philosophy is not only in the formation of a definition, although it is very relevant, but in the development of contemporary views and knowledge systems concerning this phenomenon at the philosophical and theoreticalmethodological levels. The need to analyze the philosophical and sociocultural foundations of psychological security is due to the fact that its fulfillment will allow forming not only general scientific propositions about such a complex social phenomenon, which is security, and, in particular, psychological security of the individual, but also to reveal its general properties, patterns of formation, development and functioning. 


\section{Purpose}

The purpose of the study is to analyze the philosophical and sociocultural context of the personality psychological security.

\section{Statement of basic materials}

In this study, a systematic, activity-based and subjective approaches are used to interpret the psychological security of an individual as a component of subjective security in the context of a philosophical and sociocultural understanding of this phenomenon.

The concept of "safety" in philosophy for a long time was used mainly within the framework of political philosophy, and the priority, as a rule, was given to state security, not personal or public. Today, this problem is relevant for other sections of philosophical knowledge, as well as other branches of scientific comprehension. It is important to ascertain whether there is a fundamental difference between the individual security of each personality and the collective one (the security of the whole society, community, state, etc.).

Most of the papers is devoted to definig the most effective methods and means for solving practical problems, that is, experts, talking about security, speak about specific applied understandings of this term: national (Belevsky, 2014), educational (Gerlach, \& Gockel, 2018), organizational (Chen, May, Schwoerer, \& Augelli, 2018), and other security features. In particular, studies of J. Chen, D. R. May, C. Schwoerer, B. Augelli have proved that a psychologically safe organizational environment determines the person's satisfaction with job content and career, experiencing a sense of success (Chen, May, Schwoerer, \& Augelli, 2018). Papers of B. Singkh, M. A. Schaffer, T. T. Selvarajan show that the resources of a person's social support from the organization and community, which are defined by the person's need for belonging, are indirect to psychological security of this environment (Singh, Shaffer, \& Selvarajan, 2018).

In scientific literature, the concept of security, as a rule, is interpreted differently:

1) Safety as a lack of danger (based on the principle of dichotomy). The notions of "safety" and "danger" are dialectically interrelated characteristics in the conditions of objective reality, reflecting its contradictory aspects, and may be considered as socio-philosophical categories. But this approach does not take into account the contradictions of the object-subjective sphere of human activity, which is the source of any development and change. Therefore, perhaps, the postulate that the lack of danger is security, is not perfect and requires some clarification. Such condition, in which the state, society or person is not in danger, simply does not exist.

2) Security as a certain activity to ensure or prevent threats, danger (an activity approach related to the level of social production, through which defensive actions are created). This philosophy is oriented on the value preferences of social practice (reality) and involves not only a certain level in realization of the essential contradictions of being, but also a concrete understanding of the ontological foundations in social reality.

3) Safety as a conscious necessity, value, interest, associated with goal-setting, as the key value of the motivational sphere presented in the individual and social consciousness.

All these definitions, from the point of G. G. Fesenko (2015), can be attributed to anthropological instrumentalism, within which security is associated with a certain historical practice of ensuring human life and its existence. However, security as a socio-philosophical category can not be considered only in the aspect of the state of security, since it is also the property of a certain system, and the process of social activity. 
Philosophical generalization of different approaches was made by A. P. Kruzhkov, who observes:

That security knowledge is closely connected with the socio-historical conditions of being, with the level of development of material and spiritual culture, with dominant interests and values in society, which preconceives not only the diversity of points of view, explaining the phenomenon of security, but also determines its ontological, epistemological and axiological peculiarities. (Kruzhkov, 2017, p. 360)

The ontological aspect of security lies in the fact that security, existing in the general structure of being, is in various forms, which are the optimal conditions of reality as such (being of nature, human, social and spiritual), in which dangers are minimized. Epistemological security aspect is directly related to the peculiarities of its cognition. Very important thing from the point of view of the subject in our research, is an overview concerning the socio-philosophical heritage in the domain of historical reflection of the society security and personality problem (Belevsky, 2014; Kalashnikova, 2016). In the process of historical development, security was understood through sensory experience and due to rational cognition. Stored knowledge has transformed into practical experience and reliable one. Man and society are always striving to know the desirable conditions of complete absence of danger - absolute security, which is practically impossible, because the process of danger development as a result of human activity and objective changes in the world is endless. The axiological aspect of security emphasizes that security is in a number of common human values (such as goodness, truth, beauty), since it has significance for many generations of people, despite the fact that in different eras its cultural meaning and personal meaning were understood differently. Security creates optimal conditions for supporting a harmonious state of being and sustainable development of the society. So, the security aspects mentioned are closely related. Epistemological and axiological aspects form the integral structure of the theoretical concept of security, the foundation of which is its ontological aspect (Kruzhkov, 2017).

Realities of contemporary times bring to the forefront not generalized values, but the safety and security of the life of communities, groups, individuals, regardless of their political, economic and national differences. Increasingly important are the issues of studying security, which characterize the internal state of a person, his well-being, calmness, stability, we are talking about psychological security, which is a manifestation of subjective one.

Subjective security, presented in philosophical and sociocultural aspects, can be divided to a number of interrelated issues, such as: human perception of the state of security or threat, psychological mechanisms of fear formation in the social groups (Melnyk, 2017), destruction or manipulation with identity, civic self-awareness and the ability to self-organize the community in relation to external and internal threats. Modern socio-humanitarian theories have broadened the understanding of the subjective dimension of security by including in the analytical field the problems of sociocultural, psychological and phenomenological factors affecting the perception of the individual and social groups of their own shelteredness. 
We see that scientists working in the field of philosophy, sociology, culturology, note that the psychological direction in the study of social security differs significantly from the philosophical one by the fact that in its course the study of security is refracted through interpersonal relations and the mental structure of the individual. Each individual interacts with the society, defining the standards and boundaries of this interaction for himself, producing mechanisms for effective cooperation, and if the person is not ready for mature interaction with social reality, then a favorable ground for individual's desocialization and his/her further deviation is created. This provision emphasizes the potential of interdisciplinary research linking the psychological direction of studying the social security with the philosophical and sociocultural, which, in the face of radical changes in the modern Ukrainian society, takes on particular significance.

The peculiarity of social security lies in the fact that this system has a "dual" nature. On the one hand, it is an object, that is, a person, a community, a society, demanding favorable external environment for their sustainable development. On the other hand, this social system has special, "human" qualities such as mind, will, purposefulness, which serve as a potential for protecting the individual from external and internal threats. In this case, this system acts as a subject. Consequently, the content of the social security can be regarded as a state of protection of the individual (community, society), not only from external, but also from the internal threats of human life. External threats are risks associated with an environment that threatens human life, violation of the most important rights and freedoms, and also impede the realization and development of the vital needs. Internal threats include risks related to the potential of the individual (community, society), which manifest themselves in the absence of motivation of the person's actions, as well as interaction between members of the community, society.

The application of "psychological security" concept as a separate scientific category does not yet have a long history, although it has increased considerably in scientific papers. Interest in the problems of psychological security is due to the growing need for a systematic description of rapidly changing social reality phenomena and the need to solve practical challenges of our time. In addition, traditions of the scientific description for the phenomena of reality and the person himself, change significantly - from the classical to the postnonclassical paradigm of scientific knowledge.

In the opinion of T. V. Eksakusto (Zaichenko, \& Eksakusto, 2014), it is possible to distinguish three main vectors of studying the psychology of security. First, one should highlight the psychology of safe activity that studies a person in extreme, emergency and crisis situations, where the human factor in life safety is taken into account.

Secondly, the psychological security of the environment, where the object of the study is the actual space "environment - man", and a subject is the subject-spatial, social, informational and other characteristics of the environment that can affect the psyche and human behavior. In particular, the most studied is psychological security in the educational environment (Baeva, \& Bordovskaia, 2015; Korytova, 2015; Savchenko, 2016; Zaichenko, \& Eksakusto, 2014; Kulikova, Shalaginova, \& Cherkasova, 2017). Special attention is paid to the nature of threats to the personality (negative information and psychological effects, suggestions, manipulation, etc.) and their consequences, which lead to a violation in the adequacy of the reflecting the reality, mental state, adaptability of functioning, etc.

According to H. V. Lee, J. N. Choi, S. Kim, the construct "psychological security" was developed to explain the behavior of people in an active, learning-oriented and innovation, social environment. Based on the results of cross-cultural research, the psychological security of the team is considered as an important mechanism that can explain the manifestations of creativity in 
the joint work of members in the social group. In teams with a low level of psychological security, people can not speak freely, share ideas since they concern about the possible critical feedback from other members (Lee, Choi, \& Kim, 2018). A. K. Edmondson, Z. K. Lei (2014) explicitly states that psychological security describes people's perception of the consequences of complexities in interpersonal relationships in a particular social environment, for example, in the workplace; it was organizational research that identified psychological security as an important factor in the understanding of teamwork, organizational learning, etc. We emphasize the predominantly applied nature of the research in Western science, but for us it is important that in the historical review of research on psychological security its existence, functioning and development are emphasized at the individual, group and organizational levels of analysis.

T. Kulikova, D. Maliy (2017) studied the phenomenon of psychological security in the educational environment at contemporary school. The research establishes the indicators of psychological security for the participants in the educational process and proves the existence of relationship between the level in the development of professional and personal qualities of teachers. Among them there are emotional stability, high-normative behavior, low anxiety, creative thinking, reflection, and the psychological security factor of the educational environment. The psychological security of the educational environment lies in preserving the health of participants, creating safe working and learning conditions in educational institutions that protects everyone from all forms of discrimination. Therefore, as the authors note, the issue of teacher responsibility for the development and well-being of the child in the educational process is becoming more acute. Reducing the level of psychological violence is the main focus in creating a comfortable psychologically safe educational environment.

The third direction can be designated as "subjective", where the psychological security of the individual is determined through a subjective picture of the world, safety, readiness, experience, state of consciousness, personality qualities, allowing to overcome dangers, to be resistant to negative influences, to promote the overall psychological well-being of the individual. Within the framework of this direction, psychological security refers to the positive self-sentiment of a person, his emotional, intellectual, personal and social well-being in concrete social and psychological conditions, as well as the absence of situations in infliction of psychological harm to the person and violation of his/her rights.

It is important to correlate various directions of study of psychological security with the types of scientific rationality, within the framework of which different angles, aspects, forms and types of psychological security are studied. A number of philosophical and psychological scientific papers show that the laws of the development in science are manifested through the tendencies associated with changing the types of scientific rationality that correspond to the stages of development of scientific knowledge (Zinchenko, 2011; Kalashnikova, 2016; Kruzhkov, 2017). At the classical stage of the science advancement, simple systems are the object, at the nonclassical stage complex self-regulating systems dominate; at the post-classical stage complex systems become the object that are self-development and self-organizing.

At the classical stage, the way of thinking of researchers is characterized by such features as subject-centrism, isolationism, subject-object opposition, predictability, dividing the object of research into elementary components, immediatism, rigid determination, priority of natural methodology (Galazhinsky, \& Klochko, 2012). Given these principles, psychological security is seen as the objective or subjective phenomenon, and, accordingly, it is in this dichotomy objective and subjective approaches are distinguished. The range of conceptual representations concerning the psychological security concept from the standpoint of the principles of classical rationality lies 
between the two poles: recognition of rigid dependence, the environmental conditioning of a person's mental organization, on the one hand, and recognition of internal changes related to the criteria of physical, emotional, intellectual, personal and social well-being on the other one.

Within these studies, the aspects reflecting the interrelations between a man and the surrounding natural and social reality, the active role of the individual in perceiving the threat and its overcoming, begin to be studied. This indicates about a new stage in the development of the psychological security phenomenon by scientific means of non-classical psychology (complex self-regulating systems become the subject of the study, but not simple stable systems). From the standpoint of the subject-activity approach, one should not limit himself with understanding the psychological security as a feeling, based on trust to the world, people, self, but it should be considered as more complex in structure, dynamic and associated with the activity of the person himself, directed not only the implementation of the basic needs for security, but also the need for self-development, self-realization (Zaichenko, \& Eksakusto, 2014). The center of psychological security is considered a subject as a instance holistic, active, reflexive, responsible, capable of self-development and solving the vital contradictions. Psychological security begins to be seen as an "unbalanced state" (which has no static but dynamic character) both in the internal space of the subject and in the system "man - external environment", which allows him/her to "work" not so much on survival, workout, adaptation, as on self-realization and self-development.

However, in the understanding of determinants of psychological security rely on the division of reality into subjective and objective. For researchers, as before, the situation is created, affects, and the person adapts. Researchers come to the understanding the psychological security phenomenon as a problem of a holistic person and the problem of the integrity (stability) of his being in the changing world. These contradictions lead to the task of overcoming the dichotomy of objective and subjective, internal and external, on the basis of which psychological security was viewed as a balanced state, due to safe environmental conditions. These contradictions are resolved by moving to a new level of scientific rationality (postclassical), which allows integrating the new trends from the point of view of the developing a systematic approach. Yu. P. Zinchenko points out that:

It is a systematic approach that allows us to analyze specific situations,

positions and goals in a complex of all psychological, socio-economic

and environmental factors, allow approaching to the solution for a num-

ber of topical problems of psychological security in a new way.

(Zinchenko, 2011, p. 12).

At the post-classical stage, the attention of scientists is primarily attracted by complex open systems that are capable of self-organization and self-development. Post-classical rationality is a method of scientific thinking, oriented at the dependence of knowledge on the sociocultural context, a multidimensional scientific picture of the world, when the types of rationality do not deny each other, and divide the spheres of influence among themselves; on the synthesis of theoretical and experimental research, the reflection of the values and semantic contexts of human 
existence, the interest in the progressive evolution associated with the complication of systems, its formation, the study of complex, open self-organizing systems. Based on general psychological theories about a systematic approach to the analysis of phenomena, Yu. P. Zinchenko (2011) in the context of this model proposes to understand the psychological security as the systemic phenomenon, which includes various levels of activity of the subject and over-subjective activity.

In accordance with the described trends, psychological security may be considered as a system-dynamic phenomenon that determines the self-organization of an open psychological system when it moves from danger to safety.

\section{Originality}

Psychological security is considered at different levels: first and foremost, society is a characteristic of national security, in its structure social security is present, that is an analysis of how today's social technologies, social changes affect the quality of life of the country's population; secondly, the social environment - the family, the immediate environment, reference groups, training teams; thirdly, a person is an experience of his/her own security-insecurity, when it is possible to talk about the manifestations of psychological violence, when certain behavioral acts contribute to the violation of the security of the other or to self-destruction. It is found out that the knowledge of psychological security is closely connected with the sociohistorical conditions of being, with the level of material and spiritual culture development, with the interests and values prevailing in society, determines its ontological, epistemological and axiological features. The presented issue is considered in the correlation of psychological security with types of scientific rationality - classical, nonclassical and post-nonclassical approaches, within the framework of which various perspectives, aspects, forms and types of psychological security are studied.

\section{Conclusions}

The concept of security is considered in various fields of scientific knowledge, and therefore requires a systematic description of its manifestations, types, levels, concepts: security as the absence of dangers (based on the principle of dichotomy, that is, a certain whole, consisting of two opposite parts, in this case, the whole is human existence); security as a certain activity to ensure or to prevent any threats, dangers (activity approach); security as a conscious necessity, the value of the individual.

The study systematizes various ideas about psychological security in accordance with the logic of scientific knowledge. Within the classical type of rationality, psychological security means the state of the environment, free from threatening influences (negative informational and psychological effect, manipulation, etc.), or protection from negative influence, stability, adaptability of functioning, positive self-awareness of a person, his emotional, intellectual, personal and social well-being in the specific conditions of life. At the non-classical stage of science, the principle of interaction, the idea of feedback in the form of self-regulation, that provides stability to environmental conditions, allowed to see in the phenomenon of psychological security the result of interaction between the personality and environment, treating it as a dynamic process, mediated by cognitive, personal, behavioral, activity characteristics. The post-classical approach justifies the possibility of studying psychological security from the point of view of the system approach. 


\section{REFERENCES}

Baeva, I., \& Bordovskaia, N. (2015). The psychological safety of the educational environment and the psychological well-being of Russian secondary school pupils and teachers. Psychology in Russia: State of the Art, 8(1), 86-99. (in English)

Belevsky, O. A. (2014). National security as subject of the socio-philosophical analysis. Philosophy and Political Science in the Context of Modern Culture, 7, 182-186. (in Ukrainian)

Chen, J., May, D., Schwoerer, C., \& Augelli, B. (2018). Exploring the boundaries of career calling: The moderating roles of procedural justice and psychological Safety. Journal of Career Development, 45(2), 103-116. doi: 10.1177/0894845316671214 (in English)

Edmondson, A., \& Lei, Z. (2014). Psychological safety: The history, renaissance, and future of an interpersonal construct. Annual Review of Organizational Psychology and Organizational Behavior, 1, 23-43. doi: 10.1146/annurev-orgpsych-031413-091305 (in English)

Fesenko, G. G. (2015). Urban anthropological discourse of safety philosophy. Hileya: Naukovyy Visnyk, 92(2), 166170. (in Ukrainian)

Galazhinsky, E., \& Klochko, V. (2012). System anthropological psychology: methodological foundations. Psychology in Russia: State of the Art, 5, 81-98. (in English)

Gerlach, R., \& Gockel, C. (2018). We belong together: belonging to the principal's in-group protects teachers from the negative effects of task conflict on psychological safety. School Leadership \& Management, 38(3), 302-322. doi: 10.1080/13632434.2017.1407307 (in English)

Kalashnikova, L. V. (2016). Socio-philosophical preconditions of formation of the concept of security in protosociology. Grani, 9(137), 6-13. doi: 10.15421/171672 (in Ukrainian)

Korytova, G., \& Zakotnova, Y. (2015). Psikhologicheskaya bezopastnost i zashchishchennost obrazovatelnoy sredy: faktory riski i usloviya. Bulletin Tomsk State Pedagogical University, 9 (162), 96-102. (in Russian)

Kruzhkov, A. P. (2017). Osnovnye metodologicheskie problemy issledovaniya bezopasnosti v sotsialnoy filosofii. Pozharnaya Bezopasnost: Problemy i Perspektivy, 1(8), 359-362. (in Russian)

Kulikova, T., \& Maliy, D. (2017). Professional and personal qualities of the teacher in the context of the psychological safety of educational environment. European Journal of Contemporary Education, 6(4), 715-722. doi: 10.13187/ejced.2017.4.715 (in English)

Kulikova, T., Shalaginova, K., \& Cherkasova, S. (2017). The polyethnic competence of class teacher as a resource for ensuring the psychological security of pupils in a polycultural educational environment. European Journal of Contemporary Education, 6(3), 557-564. doi: 10.13187/ejced.2017.3.557 (in English)

Lee, H., Choi, J., \& Kim, S. (2018). Does gender diversity help teams constructively manage status conflict? An evolutionary perspective of status conflict, team psychological safety, and team creativity. Organizational Behavior and Human Decision Processes, 144, 187-199. doi: 10.1016/j.obhdp.2017.09.005 (in English)

Melnyk, V. V. (2017). Fear phenomenon in existential philosophy. Anthropological Measurements of Philosophical Research, 11, 41-48. doi: 10.15802/ampr.v0i11.105476 (in English)

Savchenko, I. A. (2016). Social safety of the teacher in the educational environment: Conceptual bases. Modern scientific research and innovations. Retrieved from http://web.snauka.ru/issues/2016/03/65083 (in Russian)

Singh, B., Shaffer, M., \& Selvarajan, T. (2018). Antecedents of organizational and community embeddedness: The roles of support, psychological safety, and need to belong. Journal of Organizational Behavior, 39(3), 339354. doi: 10.1002/job.2223 (in English)

Zinchenko, Y. P. (2011). Metodologicheskie osnovy psikhologii bezopasnosti. National Psychological Journal, 2(6), 11-14. (in Russian)

Zaichenko, A. A., \& Eksakusto, T. V. (2014). Personality traits in individuals with different profiles of subjective life quality. Social Psychology and Society, 5(2), 100-114. (in English)

\section{LIST OF REFERENCE LINKS}

Baeva, I. The psychological safety of the educational environment and the psychological well-being of Russian secondary school pupils and teachers / I. Baeva, N. Bordovskaia // Psychology in Russia: State of the Art. 2015. - Vol. 8, Iss. 1. - P. 86-99.

Більовський, О. А. Національна безпека як предмет соціально-філософського аналізу / О. А. Більовський // Філософія і політологія в контексті сучасної культури. - 2014. - Вип. 7. - С. 182-186. 
Exploring the Boundaries of Career Calling: The Moderating Roles of Procedural Justice and Psychological Safety / J. Chen, D. May, C. Schwoerer, B. Augelli // Journal of Career Development. - 2018. - Vol. 45, Iss. 2. P. 103-116. doi: 10.1177/0894845316671214

Edmondson, A. Psychological Safety: The History, Renaissance, and Future of an Interpersonal Construct / A. Edmondson, Z. Lei // Annual Review of Organizational Psychology and Organizational Behavior. 2014. - Vol. 1. - P. 23-43. doi: 10.1146/annurev-orgpsych-031413-091305

Фесенко, Г. Г. Урбан-антропологічний дискурс філософії безпеки / Г. Г. Фесенко // Гілея: науковий вісник : зб. наук. пр. - Київ, 2015. - Вип. 92, Ч. 2 : Філософські науки. - С. 166-170.

Galazhinsky, E. V. System Anthropological Psychology: Methodological Foundations / E. V. Galazhinsky, V. Y. Klochko // Psychology in Russia: State of the Art. - 2012. - Vol. 5. - P. 81-98.

Gerlach, R. We belong together: Belonging to the principal's in-group protects teachers from the negative effects of task conflict on psychological safety / R. Gerlach, C. Gockel // School leadership \& management. - 2018. Vol. 38, Iss. 3. - P. 302-322. doi: 10.1080/13632434.2017.1407307

Калашнікова, Л. В. Соціально-філософські витоки становлення концепту безпеки у протосоціології / Л. В. Калашнікова // Грані. - 2016. - № 9 (137). - С. 6-13. doi: 10.15421/171672

Корытова, Г. С. Психологическая безопастность и защищенность образовательной среды: факторы риски и условия / Г. С. Корытова, Е. Ю. Закотнова // Вестник Томского государственного педагогического университета. - 2015. - № 9 (162). - С. 96-102.

Кружков, А. П. Основные методологические проблемы исследования безопасности в социальной философии / А. П. Кружков, А. К. Кокурин // Пожарная безопасность: проблемы и перспективы. - 2017. T. 1, № 8. - C. 359-362.

Kulikova, T. I. Professional and Personal Qualities of the Teacher in the Context of the Psychological Safety of Educational Environment / T. I. Kulikova, D. V. Maliy // European journal of contemporary education. 2017. - Vol. 6, Iss. 4. - P. 715-722. doi: 10.13187/ejced.2017.4.715

Kulikova, T. I. The Polyethnic Competence of Class Teacher as a Resource for Ensuring the Psychological Security of Pupils in a Polycultural Educational Environment / T. I. Kulikova, K. S. Shalaginova, S. A. Cherkasova // European journal of contemporary education. - 2017. - Vol. 6, Iss. 3. - P. 557-564. doi: $10.13187 /$ ejced.2017.3.557

Lee, H. W. Does gender diversity help teams constructively manage status conflict? An evolutionary perspective of status conflict, team psychological safety, and team creativity / H. W. Lee, J. N. Choi, S. Kim // Organizational Behavior and Human Decision Processes. - 2018. - Vol. 144. - P. 187-199. doi: 10.1016/j.obhdp.2017.09.005

Melnyk, V. V. Fear phenomenon in existential philosophy / V. V. Melnyk // Антропологічні виміри філософських досліджень. - 2017. - Вип. 11. - С. 41-48. doi: 10.15802/ampr.v0i11.105476

Савченко, И. А. Социальная безопасность учителя в образовательной среде: концептуальные основы [Электронный ресерс] / И. А. Савченко // Современные научные исследования и инноваци. - 2016. - № 3. Режим доступа: http://web.snauka.ru/issues/2016/03/65083 - Название с экрана. - Дата обращения: 14.11.2018.

Singh, B. Antecedents of organizational and community embeddedness: The roles of support, psychologicalsafety, and need to belong / B. Singh, M. Shaffer, T. Selvarajan // Journal of Organizational Behavior. - 2018. Vol. 39, Iss. 3. - P. 339-354. doi: 10.1002/job.2223

Зинченко, Ю. П. Методологические основы психологии безопасности / Ю. П. Зинченко // Национальный психологический журнал. - 2011. - № 2 (6). - С. 11-14.

Zaichenko, A. A. Personality Traits in Individuals with Different Profiles of Subjective Life Quality / A. A. Zaichenko, T. V. Eksakusto // Social Psychology and Society. - 2014. - Vol. 5, Iss. 2. - P. 100-114.

\section{о. Є. БЛИновА ${ }^{1 *}$, Л. С. ГОЛОВКОВА ${ }^{2 *}$, о. В. ШЕВяков ${ }^{3 *}$}

\footnotetext{
${ }^{1 *}$ Херсонський державний університет (Херсон, Україна), ел. пошта elena.blynova@ gmail.com, ORCID 0000-0003-3011-6082

2* Дніпропетровський національний університет залізничного транспорту імені академіка В. Лазаряна (Дніпро, Україна), ел. пошта g.liudmila22@ gmail.com, ORCID 0000-0001-5473-6644

3* Дніпровський гуманітарний університет (Дніпро, Україна), ел. пошта shevyakovy0@gmail.com, ORCID 0000-0001-8348-1935
} 


\title{
ФІЛОСОФСЬКІ ТА СОЦІОКУЛЬТУРНІ ВИМІРИ ПСИХОЛОГІЧНОЇ БЕЗПЕКИ ОСОБИСТОСТІ
}

Мета. Динаміка і темп соціально-економічних перетворень, що характерні для сучасного суспільства, призводять до зростання напруженості та руйнування звичних стереотипів - ідеалів, цінностей, норм, зразків поведінки, що об'єднують людей. Саме це спонукає до необхідності переосмислити розуміння сутності "безпеки", зокрема, психологічної, що підкреслює актуальність її вивчення у філософській та соціокультурній площині. Теоретичний базис дослідження грунтується на філософській методології К. Ясперса, Е. Фромма та психологічному підході до розуміння людини А. Маслоу. Наукова новизна. Психологічну безпеку розглянуто на різних рівнях: по-перше, суспільство - характеристика соціальної безпеки, тобто аналіз того, яким чином сьогоднішні соціальні технології, соціальні зміни впливають на забезпечення якості життя населення країни; по-друге, соціальне середовище - сім'я, найближче оточення, референтні групи, навчальні групи; по-третє, особистість - переживання своєї захищеності-незахищеності, коли можливо говорити про прояви психологічного насилля, коли певні поведінкові акти сприяють порушенню безпеки іншого або саморуйнуванню. 3'ясовано, що пізнання психологічної безпеки тісно пов'язане 3 соціальноісторичними умовами буття, з рівнем розвитку матеріальної і духовної культури, з пануючими в суспільстві інтересами і цінностями, що визначає ії онтологічну, гносеологічну та аксіологічну особливості. Порушене питання розглянуто у співвіднесенні психологічної безпеки з типами наукової раціональності - класичним, некласичним, постнекласичним, у межах яких вивчаються різні ракурси, аспекти, форми i типи психологічної безпеки. Висновки. Поняття безпеки вимагає системного опису своїх проявів, видів, рівнів, концепцій: безпека як відсутність небезпек (на основі принципу дихотомії, тобто певне ціле, яке складається 3 двох протилежних частин, в даному випадку це ціле - існування людини); безпека як певна діяльність із забезпечення або щодо попередження будь-яких загроз, небезпек (діяльнісний підхід); безпека як усвідомлена потреба, цінність особистості. Систематизовано різні уявлення про психологічну безпеку відповідно до логіки руху наукового пізнання: у класичному, некласичному та постнекласичному підходах.

Ключові слова: безпека; соціальна безпека; суб'єктивна безпека; психологічна безпека; освітня безпека; філософські та соціокультурні виміри безпеки

\section{Е. Е. БЛИНОВА ${ }^{1 *}$, Л. С. ГОЛОВКОВА ${ }^{2 *}$ А. В. ШЕВЯКОВ ${ }^{3 *}$}

\author{
${ }^{1 *}$ Херсонский государственный университет (Херсон, Украина), эл. почта elena.blynova@ gmail.com, \\ ORCID 0000-0003-3011-6082 \\ 2*2непропетровский национальный университет железнодорожного транспорта имени академика В. Лазаряна \\ (Днипро, Украина), эл. почта g.liudmila22@ gmail.com, ORCID 0000-0001-5473-6644 \\ $3^{*}$ Днипровский гуманитарный университет (Днипро, Украина), эл. почта shevyakovy0@ gmail.com, \\ ORCID 0000-0001-8348-1935
}

\section{ФИЛОСОФСКИЕ И СОЦИОКУЛЬТУРНЫЕ КООРДИНАТЫ ПСИХОЛОГИЧЕСКОЙ БЕЗОПАСНОСТИ ЛИЧНОСТИ}

Цель. Динамика и темп социально-экономических преобразований, характерных для современного общества, приводят к нарастанию напряженности и разрушению привычных стереотипов - идеалов, ценностей, норм, образцов поведения, объединяющих людей. Именно эти моменты побуждают переосмыслить сущность безопасности, в частности, психологической, что подчеркивает актуальность изучения понятия "безопасность" в философских и социокультурных координатах. Теоретический базис исследования основывается на философской методологии К. Ясперса, Э. Фромма и психолоской подходе к пониманию человека А. Маслоу. Научная новизна. Психологическая безопасность рассмотрена на разных уровнях: во-первых, общество - характеристика социальной безопасности, т. е. анализ того, каким образом сегодняшние социальные технологии, социальные изменения влияют на обеспечение качества жизни населения страны; во-вторых, социальная среда - семья, ближайшее окружение, референтные группы, учебные группы; в-третьих, личность - переживание своей защищенности-незащищенности, когда возможно говорить о проявлениях психологического насилия. Показано, что познание психологической безопасности тесно связано с социально-историческими условиями бытия, с уровнем развития материальной и духовной культуры, с господствующими в обществе интересами и ценностями, что определяет онтологическую, гносеологиче- 
скую и аксиологическую особенности. Проблема рассмотрена в соотнесении психологической безопасности с типами научной рациональности - классическим, неклассическим и постнеклассическим подходами, в рамках которых изучаются разные ракурсы, аспекты, формы и типы психологической безопасности. Выводы. Понятие безопасности требует системного описания своих проявлений, видов, уровней, концепций: безопасность как отсутствие опасности; безопасность как определенная деятельность по предупреждению угрозы или опасности (деятельностный подход); безопасность как осознанная потребность, ценность личности. Систематизированы представления о психологической безопасности в соответствии с логикой научного познания: в русле классического, неклассического и постнеклассического подходов.

Ключевые слова: безопасность; социальная безопасность; субъективная безопасность; психологическая безопасность; безопасность образования; философские и социокультурные координаты безопасности

Received: 03.05.2018

Accepted: 21.11.2018 